\title{
Open fracture of a cervical transverse process as a result of a bull-horn wound
}

\author{
Fractura abierta de apófisis cervical transversa \\ producida por herida por asta de toro
}

\author{
A. M. Hidalgo-Ovejero' ${ }^{1}$, S. García-Mata ${ }^{1}$, H. Ortiz Hurtado ${ }^{2}$, C. Yárnoz-Irazábal ${ }^{2}$, \\ M. Salvador-Bravo ${ }^{3}$, G. Jiménez-López de Oñate ${ }^{4}$
}

\section{Sr. Director:}

Bull-horn wounds are well known in Spain, many Latin-American countries, Portugal and the south of France, where frequent bullfighting festivals are held every year. These events can be either bullfights or what is known as encierros. Bullfights are spectacles where one or more toreros (i. e., bullfighters) fight and kill wild bulls in accordance with specific rules and methods. The spectacle is in some countries an ageold tradition with deep cultural and artistic associations. Encierros are races that follow protected routes along fenced-off streets, in which groups of people run in front of the bulls and lead them into rings or enclosures. Many injuries are recorded every year when bullfighters and runners are caught and gored by bulls in these events.

Bull-horn wounds can result in death, which generally occurs in association with secondary vascular lesions ${ }^{1,2}$. Spanish law requires the presence of medical and surgical personnel in bullrings, in order to provide potential victims with immediate assistance.

No open vertebral fractures caused by bull-horn wounds have so far been reported in the literature.

The case of an open cervical fracture resulting from a bull-horn wound is presented.

A 28-year-old male, professional bullfighter, suffered a bull-horn wound on the left side of his neck when he was caught by the bull as he went to kill the animal.

Following standard procedure in these cases, the patient was examined in the operating room of the bullring infirmary. Rapid clinical inspection, and central and peripheral neurological examination, revealed no abnormalities. Large amounts of non-pulsatile blood were flowing from the neck wound. Bleeding was initially contained by means of gentle compression.
1. Complejo Hospitalario de Navarra. Servicio de Traumatología

2. Complejo Hospitalario de Navarra. Área clínica de Cirugía

3. Complejo Hospitalario de Navarra. Servicio de Anestesia y Reanimación

4. Complejo Hospitalario de Navarra. Servicio de Radiología

Recepción: 31 de enero de 2011

Aceptación provisional: 14 de abril de 2011

Aceptación definitiva: 21 de junio de 2011

\section{Correspondencia:}

Angel Manuel Hidalgo Ovejero

Complejo Hospitalario de Navarra

Servicio de Traumatología

C/ Irunlarrea, 3

31008 Pamplona

E-mail: angelhidalgo@ya.com 
Surgical examination of the wound was performed under general anesthesia, with the patient intubated and a nasogastric probe in place. A section in an accessory branch of the anterior jugular vein was discovered and ligated. The wound, which was $4 \mathrm{~cm}$ long and about $12 \mathrm{~cm}$ deep, was located at the mediosuperior cervical level. It was enlarged to $8 \mathrm{~cm}$ in length to allow for adequate exploration. The major cervical vessels were intact. The upper thyroid vessels were identified, and seen to be slightly contused. The wound covered the medial third of the left sternocleidomastoid muscle, and extended into the right side on the virtual plane between the esophagus and the vertebral body. The endotracheal tube and the nasogastric probe could be palpated adequately, and did not appear to be broken to the naked eye.

Digital examination revealed a bone chip on the right vertebral side (the exact vertebra could not be ascertained accurately due to unavailability of $\mathrm{x}$-ray facili- ties). Profuse bleeding from this area was contained using hemostatic collagen material (AVITENE). The wound was washed and debrided thoroughly with saline and internal-use povidone, and two drains were placed. The skin muscle of the neck was closed. Extubation and removal of the nasogastric probe were performed uneventfully immediately after surgery.

Intravenous antibiotic therapy with cefotaxim, gentamicin and metronidazole was initiated, and antitetanic prophylaxis was administered.

A Philadelphia collar was used to immobilize the patient's cervical spine and to reduce the risk of hemorrhage.

A cervical CT-scan was subsequently performed at the hospital, revealing a fracture of the transverse process of $\mathrm{C} 4$, together with significant obliteration of the foramen of the right vertebral artery. The path of the wound was perfectly visible, with clear evidence of air penetration into the fractured transverse process (Fig. 1).

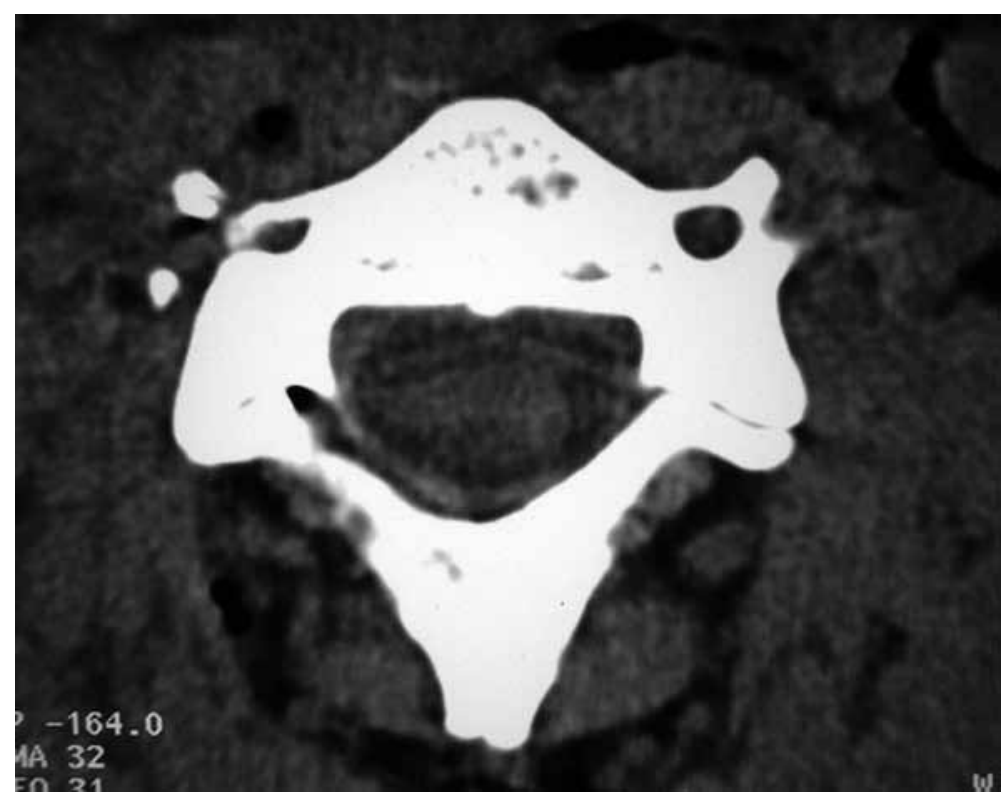

Figure 1. CAT-scan section revealing a fracture of the transverse process, with obliteration of the foramen of the right vertebral artery (A). Note the presence of air, indicating the path of the wound (B). 
Angio-MRI showed permeability and adequate blood-flow in both vertebral arteries.

Postoperative evolution was satisfactory, without infection. The drains were mobilized after 48 hours, and removed definitely after 72 hours. Cervical immobilization was maintained for 3 weeks.

The wound healed uneventfully, and the patient returned to his regular occupation, with no sequelae, one month after the injury.

Bull-horn wounds are truly idiosyncratic of our country, although they are also mentioned occasionally in some isolated international publications, mainly in connection with rural areas in Spain and India $^{3-6}$. The potential complications of these lesions are associated with the wounds themselves, and with infection caused by the dirtiness and the great amount of germs carried by the horns of bulls ${ }^{4}$. All bull-horn wounds should in fact be considered infected as a matter of course, and in one case have even been known to result in a tuberculous chancre caused by Mycobacterium bovis ${ }^{\text {? }}$.

In our milieu, these injuries involve the lower limbs and the abdomen in over $70 \%$ of cases, and $60 \%$ of the wounds follow more than one path ${ }^{8}$.

Open vertebral fractures are quite rare, and usually result from high-energy trauma or firearm injuries. It is much more uncommon for such fractures to be caused by sharp objects, and even less frequent for them to result from bull-horn wounds. We have found no similar cases reported in the literature.

In our experience, the horn of bulls tends to follow the natural muscular, fascial or vascular plane, and often causes "surgical-like" dissections that do not extend to adjacent noble structures. This was indeed what happened in our case, where the path of the wound was practically identical to the approach that is used in anterior cervical surgery. Furthermore, the elasticity of vessels usually helps them to escape from the horn; when vessels are involved, retraction of their internal and middle layers can in some instances inhibit bleeding ${ }^{8}$. In different circumstances, the lesion could have had unforeseeable consequences ${ }^{9}$, since the anatomically curved horn might have avulsed and torn the trachea ${ }^{10}$, the esophagus and the greater vessels.

Treatment should include careful examination of the wound, repair of potential lesions, exhaustive lavage, placement of drains and empirical polyantibiotic therapy.

Some authors propose the wound should be left open ${ }^{3,11}$. Our preference, however, and that of other authors in our milieu, is to close the wound over drains, without sealing it tight, after thorough lavage of the area has been performed.

The cervical fracture was not unstable, and did not therefore require additional treatment. Although lesions of the transverse processes are associated with vertebral-artery injuries in $88 \%$ of cases $^{12}$, in our patient the vertebral artery was not involved. Had this been the case, complications could have resulted from potential "incompetence" of the contralateral vertebral artery and the Willis polygon.

\section{REFERENCES}

1. Vaquero C, Arce N, Gonzalez-Fajardo J, Beltran DE Heredia J, Carrera S. A nossa experiencia nos traumatismos vasculares causados por cornos de touros. Rev Port Cir Cardiotorac Vasc 2008; 15: 217-220.

2. Saravanapavananthan N. Penetrating wound of the aorta by a bull's horn. Injury 1982; 13 : 412-413.

3. Idikula J, Moses BV, Sadhu D, Agarwal S, Jahan G, Thomas J. Bull horn injuries. Surg Gynecol Obstet 1991; 172: 220-222.

4. Martinez-Ramos D, Miralles-Tena JM, Escrig-Sos J, Traver-Martinez G, Cisneros-Reig I, SalvadorSANCHIS JL.Heridas por asta de toro en el Hospital General de Castellón. Estudio de 387 pacientes. Cir Esp 2006; 80: 16-22.

5. ShuKla HS, MitTal DK, NaIthani YP. Bull horn injury: a clinical study. Injury 1977; 9: 164-167.

6. Wasadikar PP, Paunikar RG, Deshmukh SB. Bull horn injuries in rural India. J Indian Med Assoc 1997; 95: 3-4, 16.

7. Ara M, Seral C, Baselga C, Navarro M, del Pilar Grasa M, Carapeto FJ. Primary tuberculous chancre caused by Mycobacterium bovis af- 
ter goring with a bull's horn. J Am Acad Dermatol 2000; 43: 535-537.

8. Diaz de liaño A IJ, Ederra M, Obón F. Surgical Diseases Around the World: Bull-Horn Injuries: A Nine Year Experience. Surgical Rounds 1997; 20: 481-484.

9. Lahoz Zamarro MT, Valero Ruiz J, Royo Lopez J, CAmara Jimenez F. Traumatismo abierto por asta de toro. An Otorrinolaringol Ibero Am 1990; 17: 77-84.

10. Khan MM, Ahmed SM, Shakeel M, Hasan A, Singh SP, SIDDIQI MM. Complication following pri- mary repair of a penetrating bull horn injury to the trachea. J Emerg Trauma Shock 2008; 1: 123-125.

11. Rios-Pacheco M, Pacheco-Guzman R, PadronArredondo G. Heridas por asta de toro. Experiencia de un año en Hospital General de O’Horán. Mérida, Yucatán. Cir Cir 2003; 71: 55-60.

12. Woodring JH, LeE C, Duncan V. Transverse process fractures of the cervical vertebrae: are they insignificant? J Trauma 1993; 34: 797802 . 